\title{
The introduction of the sustainability in the procedures regulated for urban planning: the case of the last act on urbanism, territory and landscape in the Valencian Community (Spain)
}

\author{
J. L. Miralles i Garcia \\ UDR F. Eiximenis. Department of Urbanism, \\ Polytechnic University of Valence, Spain
}

\begin{abstract}
The Valencian Community is located in the Spanish Mediterranean area. At present the whole Spanish Mediterranean is living through a process greatly accelerated by urban development. This process is generated, fundamentally, by the demand for housing by the population of Europe's central and northern areas in a situation of global economy. These processes suppose an irreversible transformation of the territory which is not always justified. The dysfunctions produced in these processes forced the regional Valencian government to reform, in depth, all the legislation in matters dictating new laws: Soil for non urbanize Law of 2004, Law of regional planning and protection of the landscape of 2004 and Urban development Valencian Law of 2005. This legislative wide and extensive set introduces in to urban development planning the whole set of procedures orientated to the environmental sustainability. The regulation establishes novel measurements as, amongst others, the indicators of sustainability, the quotas of sustainability to pay when the sustainability limits are exceeded, the Fund of Territorial Equity, the programs and projects for the sustainability and the quality of life, the transfer to the administration of an equal surface magnitude of natural reserve as that of any new urbanization, and the obligation of landscape studies. In spite of all this it continues without approaching an administrative reform that generates a system of management that really guarantees the protection of the natural resources in the short and long term. The present text analyzes the innovative elements that interfere for the sustainability of the urban development planning and it also indicates the still not solved aspects.
\end{abstract}

Keywords: sustainable development, urban planning, natural resource management, environmental legislation and policy. 


\section{Introduction}

The 1927s Chart of Athens already considers the city-territory idea as a whole, understanding that city and territory are not separate, defined and different spaces but two aspects of one functional unique reality. However the concept of regional planning is generated starting from the decade of 1960 [1].

In the European Union, the conceptual formation of regional planning is solved initially with the approval of the European Regional/Spatial Planning Chart adopted in 1983 at the $6^{\text {th }}$ Session of the CEMAT (European Conference of Ministers responsible for Regional/Spatial Planning), and ratified by the Committee of Secretaries of the Council of Europe in 1984.

From this date territorial planning incorporated a global vision associated with economic regional development. Territorial planning stopped being centred exclusively on cities and infrastructures, to approach the group of territory matters with some objectives concerning economic development, improvement of life quality and rational use of natural resources. However, by that time the concept of sustainable development was not still consolidated.

As Almenar et al point out [2], the concept of sustainable development presents different meanings being the definition of operative criteria essential for a clear application of the concept.

Riechman [3] synthesizes a group of 6 approaches that can de considered, by the moment, accepted with general character. Among them the principle of irreversibility zero consisting in reducing to zero the accumulative interventions and the irreversible damages produced.

Actions on territory have an essentially irreversible character. That is to say, the elements built on territory stay during a long time, so do their effects, and the return to a previous situation is generally impossible. That means, for example, that once some infrastructure like a freeway or a high-speed railroad are built, their elements will also exist during a long time and their effects, even over centuries. Similarly, once urbanization works for urban development of any area are carried out, the process is irreversible and, in case of environmental damage, it is not possible to repair the damage caused. To avoid this situation, the only and exclusive possible action is one of a preventive type, being urban and regional planning instruments important to rationalize the use of territory in order to avoid the destruction of natural resources of all type.

Nevertheless we must remember that planning is necessary but not sufficient to guarantee sustainability, and that there are also necessary new implementation and management systems in order to guarantee maintenance and to avoid the irreversible destruction of necessary natural resources in the mid-term [4].

Finally, in the meeting of Ministries responsible for Regional Planning, held in Postdam, in May of 1999, the European Union agreed a European strategy towards sustainable development [5].

\section{Introduction to the consideration of landscape in legislation}

The Spanish legislation introduced the topic of landscape for the first time in the Soil Act of 1975 and its Reacted Text of 1976. This law considered landscape as 
an environmental value to protect, a question of quality of life but not of sustainability.

There also exist in our country a group of different laws concerning Nature protection that usually include the concept of "protected landscape" and similar legal instruments of protection.

European Agreement on Landscape signed in Florence in 2000 supposed the coherent consolidation of the treatment of landscape with a global vision. Many European States have signed and ratified that agreement. As a matter of fact, Spain signed the agreement, but at the moment it has not still been ratified. In spite of this situation, the regions of Catalonia and Valencia have developed their own legislation in order to regulate questions related with landscape, following the agreements settled in the Agreement of Florence.

In Valencia, this will have two consequences: on the one hand, the change both in methodologies of elaboration and in contents of Development Plans in order to incorporate landscape aspects; on the other, landscape politics are introduced to sustainability discourse [6]. All these taking place by means of a reform of urban and territorial legislation.

The reform is carried out by means of the following autonomic or regional laws.

1. Law 4/2004, June 30, of Territorial Planning and Landscape Protection, published in July 22004.

2. Law 10/2004, December 9, of Un-Developable Land, published in December 102004.

3. Law 16/2005, December 30, of Urban Development Law published in December 312005.

Being developed by means of the following autonomic regulations.

1. Territorial and Urban Planning and Implementation Regulations. Decree 67/2006, of May 12, published in May 232006.

2. Landscape Regulation approved by Decree 120/2006, of August 11, published in August 162006.

\section{The processes of urban development in the Valencian Community}

This whole legislative reform has taken place in a situation of an extraordinary increase in urban development, mainly focused on the creation of housing, located on the Spanish Mediterranean coast and, particularly, in the coast of the Autonomous Community of Valencia.

Thus, for example, as can be observed in Tables 1 and 2, in the period from 2000 to 2004, a building boom has taken place. If we compare with Table 3, that picks up demographic evolution, there are even years in which the number of houses built were larger than the increase of inhabitants.

On the other hand, the Sustainability Report for Spain 2006 [7] points out the situation of the coast where, with data of $2005,33 \%$ of the coastal surface of the Autonomous Community of Valencia in the fringe up to $1 \mathrm{~km}$ inside from line of the coast is transformed or developed, whilst $8 \%$ of the fringe is included from an area 1 to $10 \mathrm{~km}$ inland. This data is only surpassed by Catalonia with a 35 and $13 \%$ area, respectively. 
Table 1: Visas on construction works: housing number. Source: Ministerio de Fomento.

\begin{tabular}{|c|c|c|c|c|c|c|}
\hline Year & Alicante & Castellón & Valencia & C.Valenciana & Spain & $\%$ CV/S \\
\hline & & & & & & \\
\hline 2000 & 44.447 & 12.223 & 31.234 & 87.904 & 594.820 & 14,8 \\
\hline 2001 & 40.954 & 11.401 & 27.067 & 79.422 & 561.186 & 14,2 \\
\hline 2002 & 44.426 & 13.889 & 26.625 & 84.940 & 575.546 & 14,8 \\
\hline 2003 & 53.334 & 21.608 & 31.047 & 105.989 & 690.206 & 15,4 \\
\hline 2004 & 48.230 & 20.003 & 35.909 & 104.142 & 739.658 & 14,1 \\
\hline
\end{tabular}

Table 2: Certificates of finished works: housing completed. Source: Ministerio de Fomento.

\begin{tabular}{|c|c|c|c|c|c|c|}
\hline Year & Alicante & Castellón & Valencia & C.Valenciana & Spain & $\%$ CV/S \\
\hline & & & & & & \\
\hline 2000 & 35.394 & 3.577 & 20.816 & 59.787 & 366.776 & 16,3 \\
\hline 2001 & 22.291 & 1.538 & 25.111 & 48.940 & 365.663 & 13,4 \\
\hline 2002 & 32.451 & 1.544 & 24.262 & 58.257 & 416.683 & 14 \\
\hline 2003 & 31.199 & 2.217 & 28.582 & 61.998 & 458.683 & 13,5 \\
\hline 2004 & 36.769 & 9.664 & 26.420 & 72.853 & 496.785 & 14,7 \\
\hline
\end{tabular}

Table 3: Official population data. Source: National Institute of Statistic. Local Census.

\begin{tabular}{|c|c|c|c|c|c|c|}
\hline $\begin{array}{c}\text { Year } \\
\text { (1 Jan) }\end{array}$ & Alicante & Castellón & Valencia & C.Valenciana & Spain & \% CV/S \\
\hline & & & & & & \\
\hline 2002 & 1.557 .968 & 501.237 & 2.267 .503 & 4.326 .708 & 41.837 .894 & 10,3 \\
\hline 2003 & 1.632 .349 & 518.239 & 2.320 .297 & 4.470 .885 & 42.717 .064 & 10,5 \\
\hline 2004 & 1.657 .040 & 527.345 & 2.358 .919 & 4.543 .304 & 43.197 .684 & 10,5 \\
\hline 2005 & 1.732 .389 & 543.432 & 2.416 .628 & 4.692 .449 & 44.108 .530 & 10,6 \\
\hline \multicolumn{2}{|l|}{ Provisional data: } & & & & & \\
\hline 2006 & 1.772 .270 & 555.679 & 2.444 .454 & 4.772 .403 & 44.395 .286 & 10,7 \\
\hline
\end{tabular}

The economic expansive cycle of urban development started in 1996 and is still going on.

Let us also remember that in Spain urbanization works are financed by landowners and rebounded in the price of the real estate product.

Particularly, in the Autonomous Community of Valencia the developer is a private manager who assumes the whole investment process, financing urbanization works and charging them on the landowner. This situation, with private management of the works, speeds up the urbanization processes, but it has been questioned by the European Commission. This has been one of the 
causes for the legal changes that have taken place concerning urban management. But, in spite of these, nowadays there still remains the conflict between the European Commission and the Kingdom of Spain for this reason.

\section{Sustainability and quality of life approaches in Spatial Planning and Landscape Protection Law and in Valencian's Law on Urban Development}

In the Autonomous Community of Valencia, the Law on Territorial Planning and Landscape Protection (from now on LOTPP) is the first regulation on land development to include topics concerning aspects of sustainability and quality of life. From this point of view it constitutes a legal landmark of great importance, though it has mainly the form of a group of principles that, with some exception, are not accompanied by concrete norms of direct application. Law distinguishes big groups of approaches, being the most important those referring to sustainability, and to aspects in relation with quality of life. These approaches constitute principles of obligatory application for urban and territorial planning.

On the other hand, in the case of Valencia, land planning is made through documents in which it is obligatory to distinguish between structural and detailed arrangement. The first one designs the general characteristics or structure of development and is carried out, in its graphic part, by maps on a scale from 1:5.000 to $1: 10.000$. The second settles the characteristic of partial planning and is carried out, in its graphic part, by maps on scale 1:2.000.

Based on the approaches settled down by LOTPP in 2004, the Urban Development Law of Valencia (from now on LUV) has incorporated an obligatory chapter of Guidelines with normative and linking character to all General Development Plans. These guidelines are part of the structural arrangement, having the denomination of Guidelines settled to define the strategy of urban evolution and occupation of the territory.

The guidelines are classified in three groups.

1. Guidelines concerning sustainability

1. Rational land use.

2. Efficient use of water resources, and protection of its quality.

3. Protection of natural media.

4. Conservation and valuation of cultural heritage.

5. Revitalization of rural heritage.

6. Prevention of natural or induced risks

7. Coastal arrangement.

2. Guidelines concerning citizen's quality of life.

1. Improvement of urban environments.

2. Public transport.

3. Public facilities.

4. Housing access.

3. Guidelines concerning land planning.

1. Fixing of substantive items for urban arrangement in Plan. 


\section{Development of sustainability and quality of life approaches in Regulation on Spatial and Urban Planning and Implementation}

The Regulation develops approaches and guidelines already marked in order to have them developed specifically by each Plan in each municipality. Only in some cases it establishes concrete norms of direct application.

We will point out the most prominent aspects next.

\subsection{Development of quality of life approaches}

\subsubsection{Urban environments}

- Intervention in historical cores is a general criterion, its goal being the revitalization of these nuclei.

- Construction in vacant lots turns to be obliged by means of individualized orders of building execution and even its possible expropriation.

- Integration of peripheral landscape in development is obligatory.

- Use of anti-noise screens on highways and roads when near urban plots is obligatory.

- $\quad$ Prevention of light pollution is obligatory.

- Compatibility and mixture of uses to avoid "zoning" is obligatory.

- Compact city is considered an "ideal". Previous standard on maximum density is eliminated.

- Implementation of development in existing cities is enforced to avoid developments of new sites.

- A new private investor similar to the one financing urbanization is introduced in order to finance reconstruction of old buildings and historical cores.

\subsubsection{Accessibility of citizen, mobility and public transportation}

- Elimination of architectural barriers and guarantee of accessibility for people with reduced mobility or sensorial limitation are obliged in development projects.

- $\quad$ Priority for pedestrian nets, cyclists and public transports are obligatory.

- Connections between the more significant facilities in Plan are obligatory. So is the establishment of a net of pedestrian or un-motorized itineraries.

\subsubsection{Access to housing}

- $\quad$ Plan must fix a minimum percentage of land surfaces for public housing, pointing out their localization.

General Plans will have to foresee a reserve of land of public character in order to create housing to be rented to aged, handicapped, or people under 35 years, with first and permanent residence character.

One of the criterions for selecting the developer will be the consideration of the amount of public housing offered in its development proposal. 


\subsection{Development of sustainability approaches}

\subsubsection{Rational land use}

Law establishes the obligatory creation of thresholds for consumption of resources and emission of pollutants and the Regulation defines a first threshold in form of percentage of land of new urbanization over the amount of already urbanized land. The limit is settled in a $15 \%$ or a $20 \%$ according to cases. Surpassing this limit in a Plan implies the payment of a quota of sustainability of $€ 6$ for each square metre to be developed overcoming the limit. The quota shall be paid to the Autonomous Government having finalist character to finance projects and programs of sustainability and quality of life.

In un-developable land Plan shall establish three types of areas: areas to be preserved of any development process; areas that cannot be urbanized but admit some constructions according to Un-Developable land Law; and areas that can be reclassified to developable land always fulfilling the sustainability thresholds or paying, if necessary, the sustainability quota to overcome them.

Reclassification of un-developable to developable land through any of the procedures foreseen in Law (mainly by the revision of the effective plan or by partial plans that reclassify floor), implies the free surrender to public administration of an amount of protected un-developable land of similar amount to the one reclassified.

This is known by the rule of " 1 by 1. ." This way for example, a new development of 1.000 .000 of square metres obliges to surrender to administration an equal amount of protected un-developable land to be acquired previously, or paid during the process of implementation of urban development.

These surrenders are considered natural park facilities, being additional to those of secondary level such as streets, little parks, and facilities of local character that should also be carried out to administration. The surrender of natural parks is only excepted when administration carries out developments for public housing.

\subsubsection{Prevention of natural or induced risks}

Land affected by forest fires cannot be developed and, if previously protected, this protection cannot disappear due to the disappearance of vegetal cover.

Woodland of interest should be either integrated in developments, or replaced in identical proportion, with the same species and similar size.

Introduction seismic risks insurance.

Prevention of erosion risks in planning.

Protection of river's beds gullies with hydrological function, and of biological corridors.

Incorporation of all determinations included in Territorial Action Plan against Flood Risk in the Autonomous Community of Valencia, already passed by 2003.

\subsubsection{Coastal arrangement}

Dune's system and coastal vegetation are protected.

In urban developments held in coastal zones buildings shall not occupy over $30 \%$ of the surface developed until the Action Plan for Littoral is edited. Thus, 
coastal zones are defined as the amount of land up to $1 \mathrm{~km}$. from the line that separates sea form land in administrative terms, being this piece of land competence of municipality.

\subsubsection{Water resources}

Water resources are protected in any of its types: superficial or subterranean. Water captures are also protected.

When editing a Plan it is obliged to make a study on water resources in order to valuate the amount and quality of water available for all uses including purified water able for new uses.

A report from the basin agent or from the entity in charge of water supply is needed as a previous condition to pass any urban development. In the event of water not being sufficient its acquisition by means of technologies like desalination is permitted being its cost charged to development.

General Plans are obliged to limit the amount of land to be developed if water resources are not enough for the new activities.

\subsubsection{Conservation and Improvement of cultural heritage}

There establishes the continuity of previous criterions such as the edition of Catalogues of Protected Real Sate and/or Natural Sites.

\subsubsection{Conservation and Improvement of rural heritage}

It also establishes the continuity of previous criterions to preserve rural heritage such as the respect of building typologies and urban landscape of rural nuclei.

\subsubsection{Infrastructures and it improvement of energy resources}

- $\quad$ Plans are obliged to define corridors in which to settle all infrastructures, thus avoiding its dispersion through territory.

- Infrastructures necessary for new developments shall be charged on developments.

- $\quad$ Plans are obliged to settle places for selective collection and treatment of disposals. These areas shall be considered facilities of public character.

- Instruments to follow and control light, noise and air pollution shall be introduced.

\section{Development of Regulation on Landscape}

This Regulation completes sustainability matters. To do so it makes landscape plans to be integrated to the contents and processes of urban and territorial planning.

The Regulation on Landscape includes very detailed descriptions and regulations of the contents and objectives of landscape studies to be obligatory carried out in the process of edition of general and other development plans.

It includes a previous process of public participation with the objective of obtaining public valuation of existent landscapes in order to take decisions on the urban and territorial environments to be transformed, regenerated, conserved or developed. 


\section{Conclusions}

The legal figure exposed in a very synthetic way supposes a very remarkable effort to incorporate in an operative way sustainability and landscape arrangement criterions to urban planning.

Of special interest is the incorporation of landscape arrangements to urban planning. However, the extraordinary speed with which both Developable Land Law and Regulation on Territorial and Urban Planning and Implementation have been edited and passed has had, as a consequence, the approval of very extensive texts sometimes contradictory or disjointed; particularly, and for example, the rule of the " 1 by 1 " is designed to be carried out by a procedure that generates doubts for its real application.

We can conclude therefore, that though it has been a very remarkable effort in order to incorporate operative sustainability approaches to urban planning, in spite of their novelty, a process of revision and adjustment both of the Laws/Norms and of the administrative procedures are needed in order to really fulfil its objectives.

\section{References}

[1] Sáenz de Buruaga, G., Sentido de la ordenación territorial en la España actual. Estudios Territoriales, 7, pp. 17-24, 1982.

[2] Almenar Asensio, R., Bono Martínez, E. \& Garcia Garcia, E., La sostenibilidad del desarrollo: el caso valenciano, Fundació Bancaixa, pp. 19-56, 1998.

[3] Riechman, J., Desarrollo sostenible: la lucha por la interpretación (Chapter 1). De la economía a la ecología. Editorial Trotta, S.A.: Madrid, pp 11-36, 1995.

[4] Miralles i Garcia, J.L. \& Gaja i Díaz, F., Proposal for to Natural Capital Bank as a managing tool for urban management sustainability. The Sustainable City II. Urban Regeneration and Sustainability, eds. C.A. Brebbia, J.F. Martin-Duque \& L.C. Wadhwa, WIT Press \& Computational Mechanics Inc: Southampton and Billerica, pp 477-486, 2002.

[5] ESDP European Spatial Development Perspective. Towards Balanced and Sustainable Development of the Territory.of the Europena Union. European Commission, http://ec.europa.eu/regional_policy/sources /docoffic/official/reports/pdf/sum_en.pdf

[6] Miralles i Garcia, J.L., Introducción a las técnicas de planificación en la ordenación del territorio (Chapter 12). Proyectos de regeneración del paisaje, eds. J.F. Ballester Olmos y Anguís, Valencia, pp 219-240, 2005.

[7] Evaluación Integrada. Informe Sostenibilidad en España 2006, http://www.sostenibilidad-

es.org/NR/rdonlyres/000000e5/ooxwdrxarrytykjalilbuodeqkrgnlyo/Evalua ci\%C3\%B3nIntegrada.pdf 